\title{
РОЗВИТОК ТА НАПРЯМИ ПІДВИЩЕННЯ ЕФЕКТИВНОСТІ ЗЕРНОВИРОБНИЦТВА СІЛЬСЬКОГОСПОДАРСЬКИХ ПІДПРИЕМСТВ УКРАЇНИ
}

\section{DEVELOPMENT AND DIRECTIONS OF INCREASING THE GRAIN PRODUCTION EFFICIENCY OF AGRICULTURAL ENTERPRISES OF UKRAINE}

\author{
Гаража Олена Петрівна \\ доктор економічних наук, доцент, \\ Харківський національний аграрний університет \\ імені В.В. Докучаєва \\ ORCID: https://orcid.org/0000-0001-9986-6231
}

\author{
Garazha Olena \\ Kharkiv National Agrarian University named after V.V. Dokuchaiev
}

\begin{abstract}
Стаття присвячена розвитку та напрямам підвищення ефективності зерновиробництва сільськогосподарських підприємств України. Метою статті є розробка теоретичних та методологічних положень, обґрунтування науково-практичних рекомендацій стосовно підвищення ефективності зерновиробництва сільськогосподарських підприємств. Об'єктом дослідження стали ресурсно-економічні процеси зерновиробництва аграрних підприємств. Обґрунтована важливість розвитку виробництва зернових та зернобобових культур, які в сучасних ринкових умовах стають прибутковою експортною та конкурентоспроможною агропродукцією на зовнішньому ринку. У статті розглянуто структуру посівних площ зернових та зернобобових культур за період 1990-2020 рр. Проаналізовано урожайність та обсяг виробництва зернових та зернобобових культур за період 1990-2020 рр. Досліджено виробництво зерна на одну особу в розрізі регіонів України. Розглянуто вплив розміру посівної площі на обсяг та урожайність зернових та зернобобових культур, зокрема пшениці та кукурудзи на зерно.

Ключові слова: зернові та зернобобові культури, підприємство, обсяг виробництва, урожайність, посівна площа.
\end{abstract}

Статья посвящена развитию и направлениям повышения эффективности зернопроизводства сельскохозяйственных предприятий Украины. Целью статьи является разработка теоретических и методологических положений, обоснование научно-практических рекомендаций по повышению эффективности зернопроизводства сельскохозяйственных предприятий. Объектом исследования стали ресурсно-экономические процессы зернопроизводства аграрных предприятий. Обоснована важность развития производства зерновых и зернобобовых культур, которые в современных рыночных условиях становятся прибыльной экспортной и конкурентоспособной агропродукцией на внешнем рынке. В статье рассмотрена структура посевных площадей зерновых и зернобобовых культур за период 1990-2020 гг. Проанализированы урожайность и объем производства зерновых и зернобобовых культур за период 1990-2020 гг. Исследовано производство зерна на душу населения в разрезе регионов Украины. Рассмотрено влияние размера посевной площади на объем и урожайность зерновых и зернобобовых культур, в частности пшеницы и кукурузы на зерно.

Ключевые слова: зерновые и зернобобовые культуры, предприятие, объем производства, урожайность, посевная площадь.

The article is devoted to the development and directions of increasing the grain production efficiency of agricultural enterprises of Ukraine. The purpose of the article is development of theoretical and methodological provisions, substantiation of scientific and practical recommendations for improving the efficiency of grain production of agricultural enterprises. The research object was the resource and economic processes of grain production of agricultural enterprises. The importance of grain and leguminous crops production development which in modern market conditions become profitable export and competitive agricultural production in the foreign market has been substantiated. The structure of sown areas of cereals and legumes for the period 1990-2020 has been considered in the article. The yield and volume of grain and legumes production for the period 1990-2020 have been analyzed. The produc- 
tion of grain per person in the context of the regions of Ukraine has been studied. The influence of the sown area size on the volume and yield of cereals and legumes, in particular wheat and corn on grain has been considered. It has substantiated that one of the main tasks for today is to develop production increasing of cereals and legumes, which will positively affect the creation of new jobs, increase wages, increase the requirements for their skills on the basis of its competitiveness and export orientation to foreign markets for agricultural products by growing quality products that accord international standards. Thus, today grain production is the most profitable industry, especially the cultivation of corn for grain and wheat, so there is an increase in sown areas of these crops regardless of climatic zone and recommended crops, increase their yield and productivity, increase grain production per capita in regions, and there is a concentration of grain production. One of the key areas to increase the efficiency of growing cereals and legumes should be: a larger area of crops of cereals and legumes, which will increase yields and gross harvest, because there are more opportunities for the introduction of new technologies, mineral and organic fertilizers, high-yielding seed, production of quality products, and the available scale for its sale than small producers; as well as further research deserve issues of increasing yields in small farms with low yields, eliminating restrictions on the market, improving sales prices and quality of products grown.

Keywords: cereals and legumes, enterprise, production volume, yield, sown area.

Постановка проблеми. Стратегічним напрямом розвитку сільського господарства є виробництво зернових культур у сільськогосподарських підприємствах, яке створює не тільки продовольчу безпеку держави, але й постачає сировину для агропромислового комплексу, забезпечує зерно-фруражними та іншими кормами галузь тваринництва, створює потужний експортний потенціал міжнародного рівня та стає джерелом наповнення державного бюджету. Вирощуванню високоякісного продовольчого зерна сприяють родючі ґрунти, природні та кліматичні фрактори, зручне просторово-територіальне місцеположення. Зернова галузь забезпечує населення країни хлібом та хлібобулочними виробами, кондитерськими, круп'яними, макаронними та іншими харчовими виробами, які фрормують основу споживчого кошика середньостатистичного українця. Для роботи у зерновій галузі та переробній промисловості залучаються трудові ресурси та кваліфріковані кадри, що створює додаткові робочі місця населенню. Мінливість ринкових умов, нестабільність політико-економічної ситуації, трансорормація аграрних та земельних відносин, низький рівень державної підтримки негативно впливають на діяльність сільськогосподарських підприємств. Водночас, розширене відтворення із залученням новітніх інноваційних технологій вирощування зернових культур в аграрних підприємствах обмежується такими дестабілізуючими фракторами як зміни клімату, невигідні умови кредитування, низька фрінансово-економічна спроможність товаровиробників. Відтак, аналіз зерновиробництва стає гострим та актуальним питанням, а підвищення рівня урожайності зернових культур стає головним орієнтиром формування економічної стабільності держави.

Аналіз останніх досліджень і публікацій. Аналізуючи праці вітчизняних вчених-економістів виділено основні напрями дослідження зерновиробництва в контексті підвищення врожайності зернових культур, покращення якісних показників зерна, маркетингу та збуту вирощеного врожаю зернових, ефективності виробництва зернової продукції. С. О. Заїка, Р. Р. Романова, В. О. Курган вказують на те, що ефективність відображає залежність кінцевого результату від використання відповідних засобів виробництва та кількості затраченої живої праці, а основним показником оцінки економічної ефрективності у сільськогосподарському виробництві $\epsilon$ зростання виробництва продукції за найменших витрат живої та уречевленої праці, а також раціональному використанні усіх наявних ресурсів (трудових, матеріальних, орінансових, земельних), тому кінцевим очікуваним результатом тут є обсяг валової продукції без спожитих засобів виробництва (амортизаційних відрахувань, вартості насіння тощо) [1, с. 40]. О. О. Гуторова, О. М. Стасенко підкреслюють, що інтенсифрікація виробництва, яка виступає як напрям розширеного відтворення зерновиробництва забезпечується існуванням та використанням науково-технічного процесу, а агротехнічні прийоми дають змогу максимально реалізовувати генетичний потенціал сортів і одержувати урожайність у 2-3 рази вищу, ніж забезпечують природні біокліматичні фракторії місцевості [2, с. 23]. О. О. Сосновська, С. О. Білун, О. П. Бурлака підкреслюють, що збільшення врожайності впливає не тільки на збільшення валового збору зерна, але і на економічну ефрективність його виробництва: продуктивність праці, собівартість, a, отже, і на рентабельність [3, с. 286]. Г. М. Христенко наголошує, що зерновий ринок регіону спроможний забезпечити високі валові збори зернових культур за рахунок підвищення їх урожайності на базі інноваційних технологій вирощування, селекції, збільшення внесення мінеральних та органічних добрив [4, с. 184]. Л. В. Забуранна 
вказує на те, що нині серед більшості зерновиробників існує практика «продати те, що вироблено» замість «виробляти те, що продається». Останнє відповідає виробничій концепції маркетингу, суть якої полягає в збільшенні обсягів виробництва при зменшенні витрат і практично «автоматично» веде до зростання продажів, a, отже, до збільшення прибутку [5, с. 56]. Водночас, окремі аспекти досліджуваної проблеми потребують більш поглибленого вивчення та особливого наукового пошуку. Авторський погляд сфрокусований на доречності системного дослідження специоріки зерновиробництва, яке відрізняється від інших галузей сільського господарства тим, що є стратегічною галуззю аграрної ссрери, фрормує продовольчу безпеку, має значний експортний потенціал тощо.

Формулювання цілей статті. Метою дослідження $€$ розробка теоретичних та методологічних положень, обґрунтування науковопрактичних рекомендацій стосовно підвищення есрективності зерновиробництва сільськогосподарських підприємств. Об'єктом дослідження стали ресурсно-економічні процеси зерновиробництва аграрних підприємств. В основу методики дослідження покладено загальнонаукові методи: діалектичний підхід до вивчення явищ, процесів; наукового абстрагування до фрормулювання узагальнень, положень, висновків; системний підхід до аналізу взаємодії ресурсних елементів зерновиробництва. Специфрічними методами стали статистичні методи групування для визначення залежності між розміром землекористування та урожайністю і обсягами виробництва зернових культур, економіко-статистичні методи для вивчення та виявлення тенденцій і закономірностей розвитку виробництва зернових культур, розрахунково-конструктивні методи використані для аналізу економічних процесів розвитку.

Виклад основного матеріалу дослідження. Сприятливий клімат, високоякісні характеристики складу ґрунту, помірна кількість опадів - усі ці фрактори сприяють вирощуванню зернових культур, при цьому отримуючи якісне продовольче та фруражне зерно в таких обсягах, які здатні забезпечити внутрішні потреби та сорормувати високі експортні можливості. Проте виробництво зерна має й низку проблем, які включають низький рівень матеріально-технічного забезпечення, яке не відповідає потребам галузі, недостатнє фрінансування оновлення техніки і технологій тощо [1, с. 40]. Розвиток галузі рослинництва характеризується можливістю одержання прибутку за рахунок експорту зерна за кордон по вигідним цінам. Тому дослідження структури та розмірів посівних площ дасть можливість виділити найбільш дохідні сільськогосподарські культури, на які є споживчий попит закордонних імпортерів зернової продукції.

Протягом 1990-2020 рр. посівна площа під зерновими та зернобобовими культурами знизилась на 20,7 \% і становила 11251,1 тис. га або 79,3 \% на кінець періоду дослідження. Поряд 3 цим, посіви зернових культур зменшилися на $14 \%$ і зайняли 10988,7 тис. га або 86 \% у 2020 р. у порівнянні з початком періоду дослідження. Аналогічна негативна ситуація щодо зменшення посівних площ спостерігається в розрізі сільськогосподарських культур (пшениця, пшениця озима, жито, жито озиме, ячмінь, ячмінь ярий, овес, просо, гречка, рис). Збільшення посівів майже у 4 рази відбулося тільки по кукурудзі на зерно, вирощування якої стало вигідним через можливість експортування на світовий та європейський ринок. У структурі посівних площ посіви озимої пшениці майже не змінилися і становили 24,7\% (1990р.) та 24,8 \% (2020р.), аналогічно по рису та просу. Проте, збільшення ваги у структурі посівів кукурудзи на зерно відбулося майже на 18,8 \% або з 3,3 \% на початку періоду дослідження до 22,1 \% на кінець. Збільшення зернових у структурі посівів відбулося на 13,8 \%, а зернових та зернобобових - на 10,4 \%. При чому нарощування виробництва зернових та зернобобових культур відбувається у всіх природно-кліматичних зонах України, не зважаючи на рекомендовані та районовані сільськогосподарські культури для цих регіонів, бо для аграрних підприємств це стає єдиною можливістю одержати прибуток та зберегти виробничу діяльність в мінливих умовах ринку (табл. 1).

Обсяги виробництва зернових культур зросли на 10,5\%, а культур зернових та зернобобових - на 4,3\%. Майже у 6,9 разів збільшилось виробництво кукурудзи на зерно та становило 26280,2 тис. т у 2020 р. Проте, обсяги виробництва зернобобових культур зменшилися на 84,1 \% та становили 513,5 тис. т у 2020 р. (табл. 2).

Порівнюючи урожайність пшениці 1990 р. та 2020 р. приходимо до висновку, що вона майже не змінилася (розбіжність у $1 \%$ або 0,4 ц/га) і становила 39,8 ц/га на кінець періоду дослідження. Позитива тенденція спостерігається по житу, де зростання відбулося на 53,1 \% і становило 37,2 ц/га у 2020 р. проти 24,3 ц/га у 1990 р. Найбільше урожайність зросла у кукурудзи на зерно з 37,9 ц/га у 1990 р. до 60,9 ц/га у 2020 р. або на 60,7 \%, або на 23 ц/га (табл. 3). 


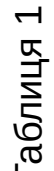

욷유

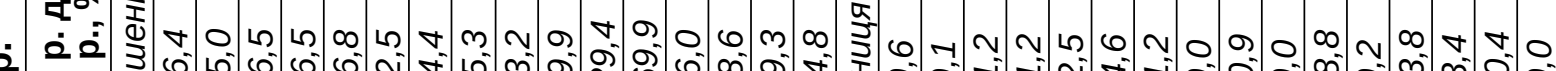

र요 ㅇํำ

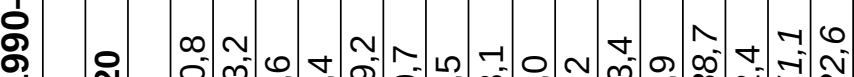

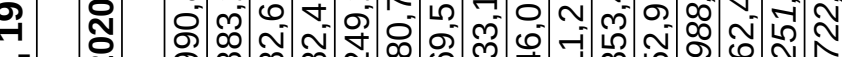

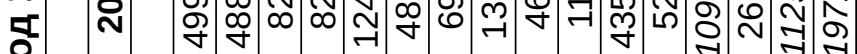

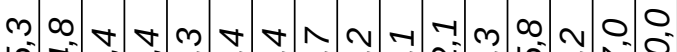

ขึ

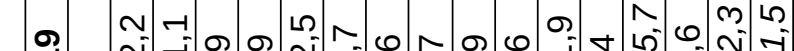

ส- 3 -

N กิ

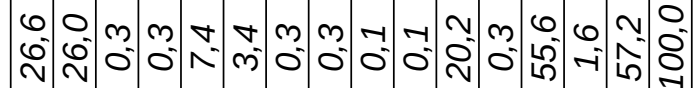

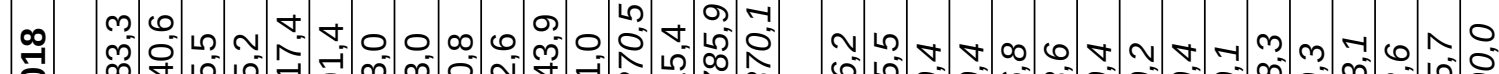

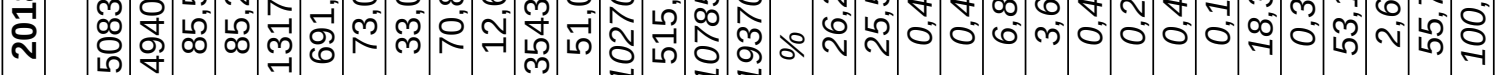

흘

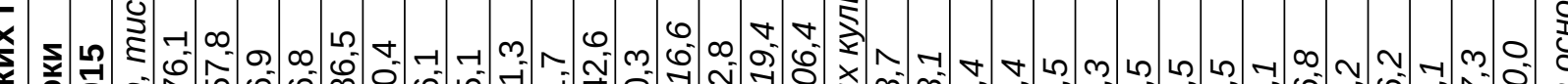

हो

○

.

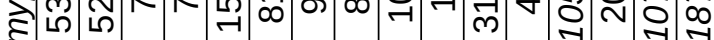

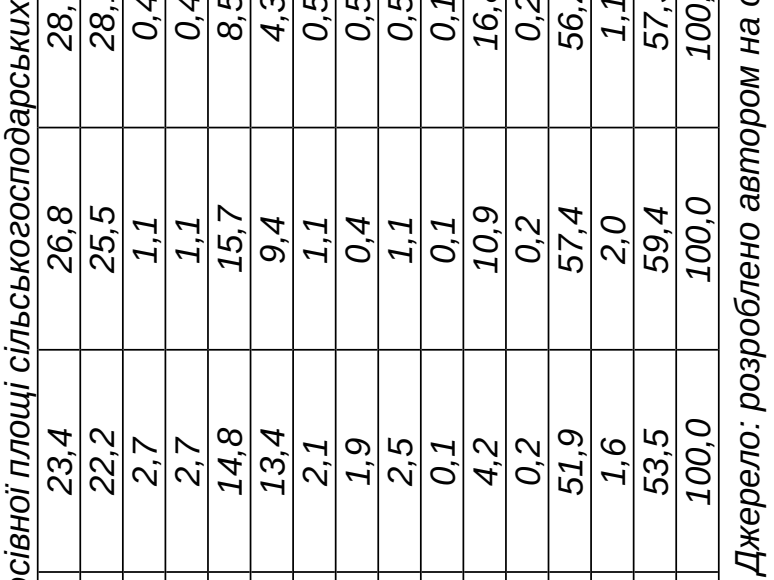

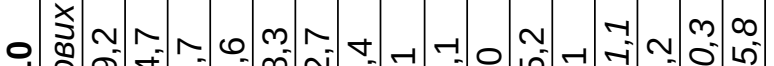

ด Dी

నิ

$\rightarrow$ 章

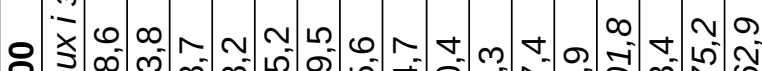

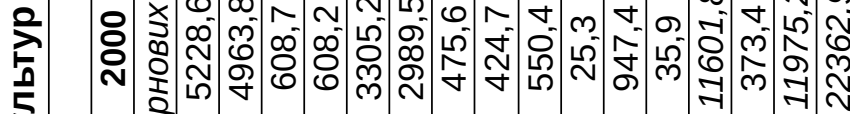

x

离

-

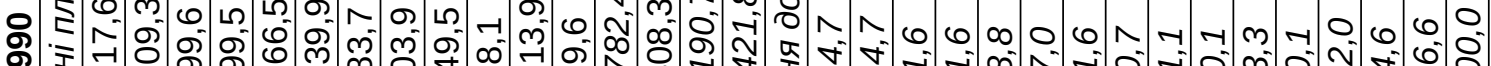

○

: \&

ป̂ं

옹 


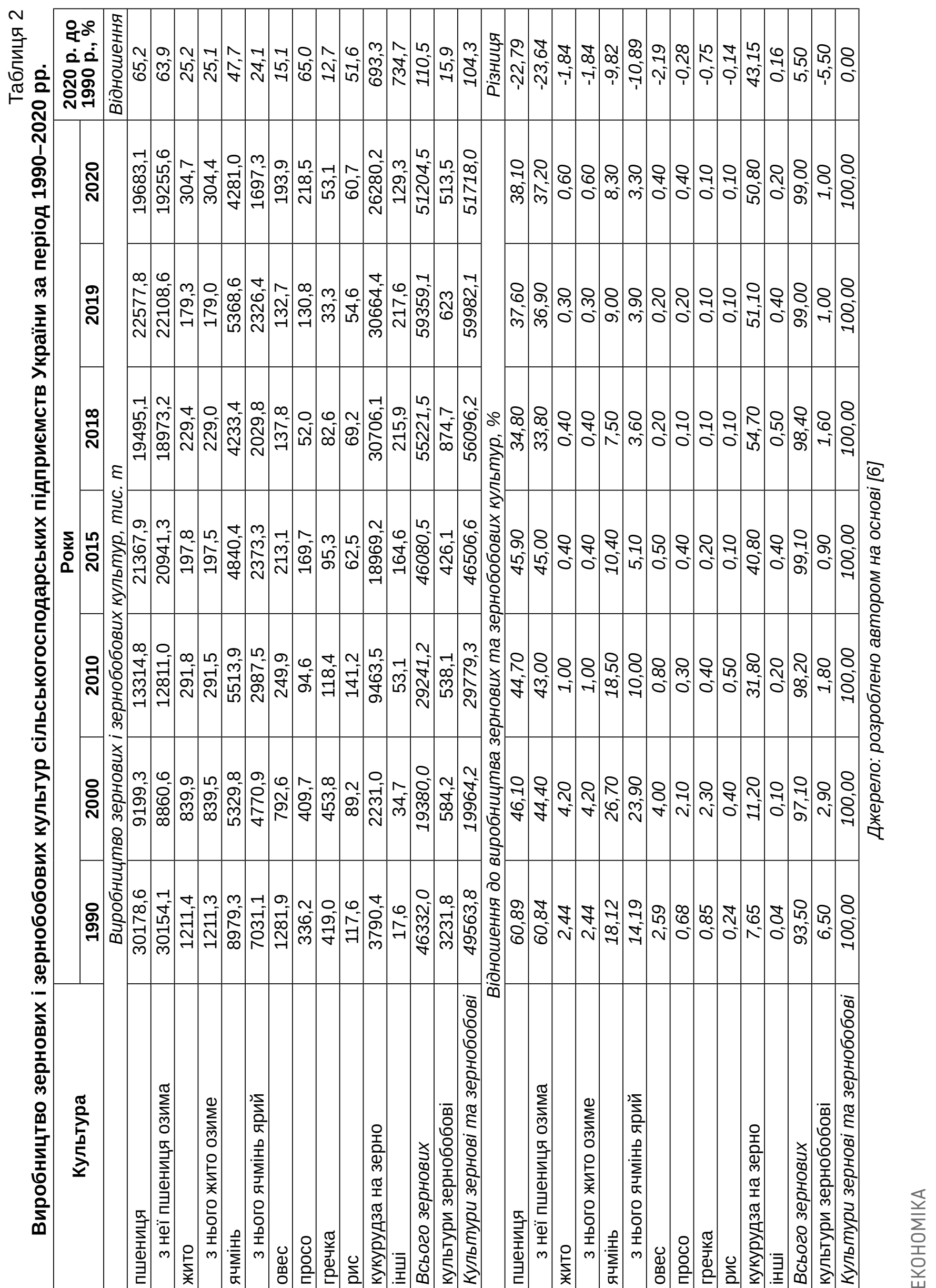




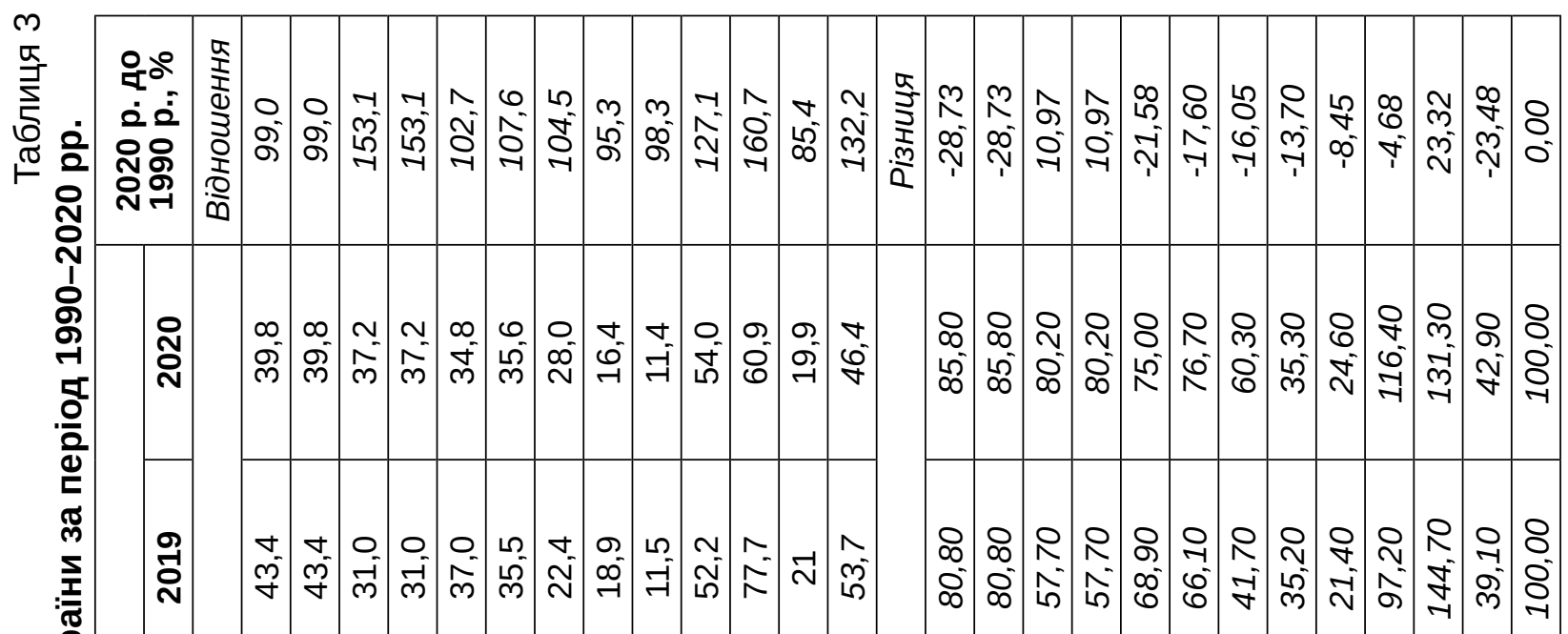

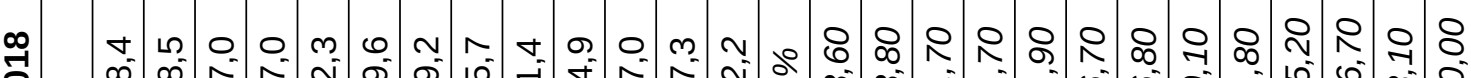

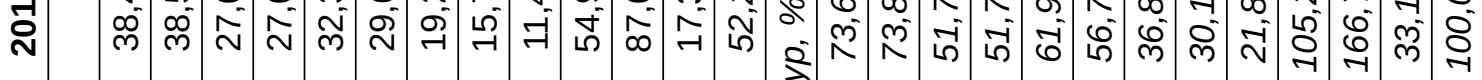

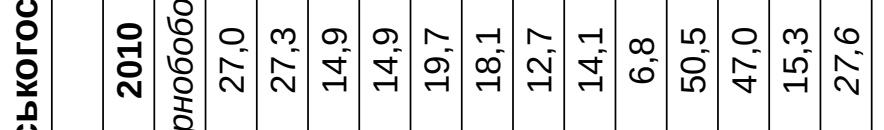
ஃ

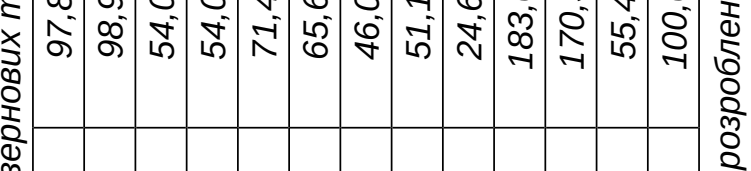

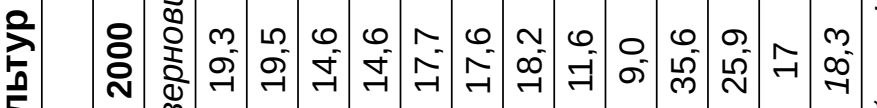

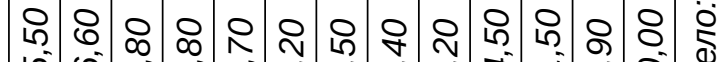

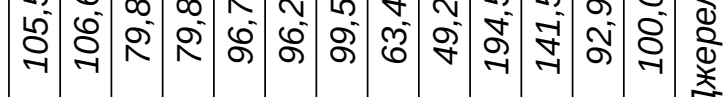

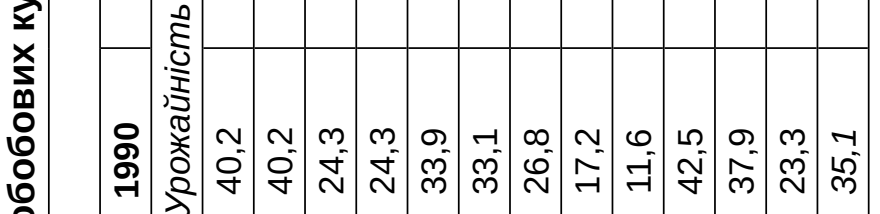
$\frac{8}{2}$

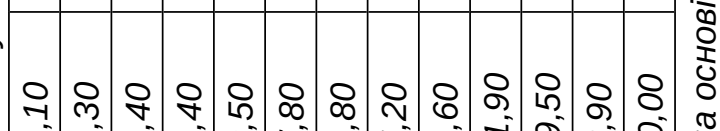
ने कं की ఇ

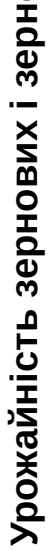
चี

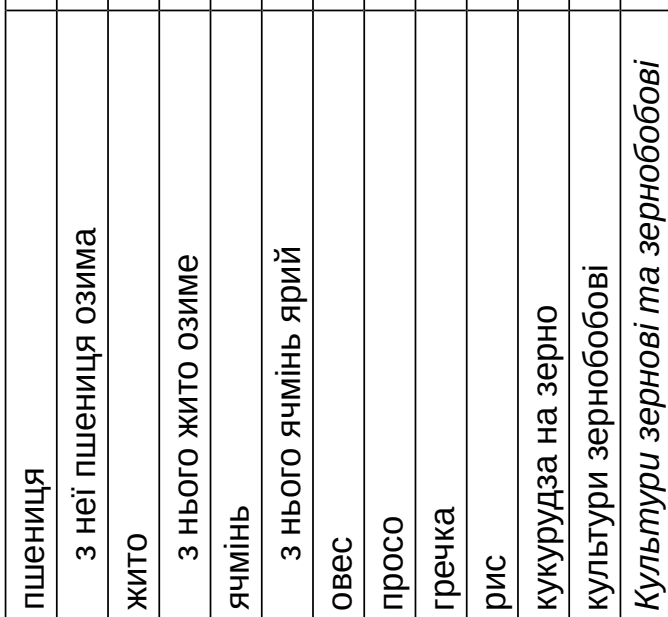
ำ

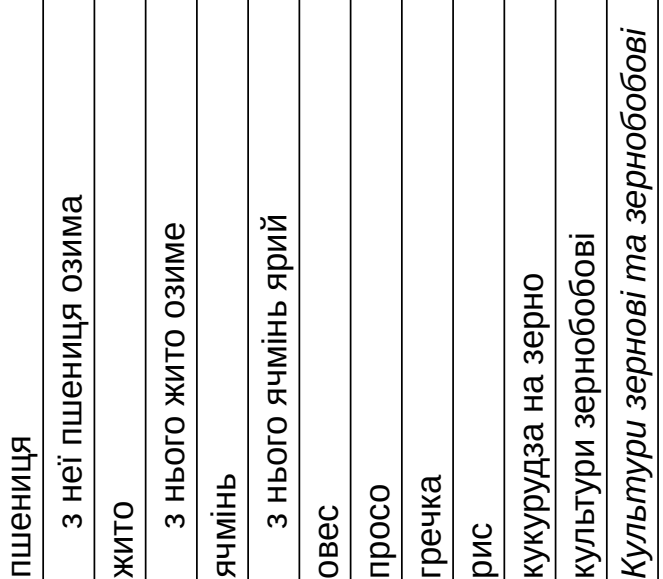


Найбільший відсоток підприємств 58,5\% вирощували у 2020 р. зернові та зернобобові культури на площі до 100 га, де спостерігаються найнижчі обсяги виробництва 3,7 \% та найнижча урожайність 30,2 ц/га. Найменша кількість (504) підприємства вирощують зернові та зернобобові на площі більше 3000 га і одержали найвищу врожайність 56,6 ц/га та найбільший обсяг виробництва 30,5\%. Група від 1000,01-2000,00 га з кількістю підприємств 5,8 \% посіла друге місце з обсягом виробництва $22,6 \%$ і врожайністю 46,3 ц/га. Таким чином, аналіз виробництва зернових та зернобобових показує, що при найбільшій площі збору врожаю досягається максимальний обсяг виробництва та найвища урожайність, завдяки застосуванню високоврожайних сортів зернових та зернобобових культур, застосуванні новітніх технологій їх вирощування (табл. 4).

Найбільша кількість підприємств $63 \%$ вирощують пшеницю на площі до 100 га з найменшим обсягом виробництва 7,8 \% і найнижчою урожайністю 31,7 ц/га. Найвища урожайність 44 ц/га у підприємств 3 площею більше
3000 га, але їх кількість найменша - 0,4 \% від загальної кількості та невеликий обсяг виробництва 9,3 \%. Найбільший та майже однаковий обсяг виробництва пшениці 20 \%, 23,3 \% та 23,2 \% спостерігається у трьох групах відповідно 200,01-500,00 га, 500,01-1000,00 га, 1000,01-2000,00 га, які мають приблизно однаковий рівень врожайності пшениці відповідно 38,8 ц/га, 40,5 ц/га, 42,0 ц/га при поступовому скороченні кількості підприємств у групах 3 більшою площею відповідно 13,4 \%, 6,9 \%, 3,3 \%. Відтак, максимальний обсяг виробництва одержують підприємства з площі пшениці від 200 до 2000 га і при цьому їх врожайність відрізняється від найвищої (44 ц/га) лише на 2-5,2 ц/га, що свідчить при високий рівень технології вирощування пшениці (табл. 5).

Чим більша площа вирощування кукурудзи на зерно, тим вища урожайність в цій групі підприємств, але кількість підприємств найменша. На підтвердження цьому положенню в групі підприємств, які вирощують кукурудзу на зерно на площі більше 3000 га найвища урожайність 68,9 ц/га 3 найвищим обсягом

Таблиця 4

Групування сільськогосподарських підприємств України за розмірами зібраної площі зернових та зернобобових культур у 2020 р.

\begin{tabular}{|l|c|c|c|c|c|}
\hline \multirow{2}{*}{ Площа, га } & \multicolumn{2}{|c|}{ Кількість підприємств } & \multicolumn{2}{|c|}{ Обсяг виробництва } & Урожайність, \\
\cline { 2 - 4 } & од. & \% & тис. т & \% & (га, \\
\hline до 100,00 & 19026 & 58,5 & 1934,0 & 3,7 & 30,2 \\
\hline $100,01-200,00$ & 3559 & 10,9 & 1899,5 & 3,7 & 36,6 \\
\hline $200,01-500,00$ & 4213 & 13,0 & 5410,0 & 10,5 & 40,0 \\
\hline $500,01-1000,00$ & 2765 & 8,5 & 8300,4 & 16,1 & 42,2 \\
\hline $1000,01-2000,00$ & 1880 & 5,8 & 11694,6 & 22,6 & 46,3 \\
\hline $2000,01-3000,00$ & 566 & 1,7 & 6694,1 & 12,9 & 48,6 \\
\hline більше 3000,00 & 504 & 1,6 & 15785,4 & 30,5 & 56,6 \\
\hline Всього по підприємствам & 32513 & 100,0 & 51718,0 & 100,0 & 46,4 \\
\hline
\end{tabular}

Джерело: розроблено автором на основі [6]

Таблиця 5

Групування сільськогосподарських підприємств України за розмірами зібраної площі пшениці у 2020 р.

\begin{tabular}{|l|c|c|c|c|c|}
\hline \multirow{2}{*}{ Площа, га } & \multicolumn{2}{|c|}{ Кількість підприємств } & \multicolumn{2}{|c|}{ Обсяг виробництва } & Урожайність, \\
\cline { 2 - 5 } & од. & \% & тис. т & \% & (га, \\
\hline до 100,00 & 14730 & 63,0 & 1543,0 & 7,8 & 31,7 \\
\hline $100,01-200,00$ & 2867 & 12,3 & 1550,1 & 7,9 & 36,4 \\
\hline $200,01-500,00$ & 3132 & 13,4 & 3948,2 & 20,0 & 38,8 \\
\hline $500,01-1000,00$ & 1613 & 6,9 & 4580,4 & 23,3 & 40,5 \\
\hline $1000,01-2000,00$ & 775 & 3,3 & 4558,7 & 23,2 & 42,0 \\
\hline $2000,01-3000,00$ & 161 & 0,7 & 1666,2 & 8,5 & 42,9 \\
\hline більше 3000,00 & 97 & 0,4 & 1836,5 & 9,3 & 44,0 \\
\hline Всього по підприємствам & 23375 & 100,0 & 19683,1 & 100,0 & 39,8 \\
\hline
\end{tabular}


виробництва 31,1 \%, але невелика їх кількість - 1,4 \%. В більшості підприємств (59,4 \%) вирощують кукурудзу на зерно з найменшим обсягом виробництва $5 \%$ і найнижчою врожайністю - 41,6 ц/га. При зборі врожаю на площі від 200 до 2000 га, яка відповідає трьом групам, спостерігається майже однаковий обсяг виробництва кукурудзи на зерно відповідно 14,5 \%, 15,5 \%, 17,7 \% 3 урожайністю, яка коливається від 55,4 до 62,9 ц/га і відрізняється від найвищої на 6-13,5 ц/га. Середня урожайність кукурудзи на зерно по Україні становила 60,9 ц/га, іiї перевищення спостерігається у групі з площею збору врожаю від 1000 га. Таким чином, для виробництва кукурудзи на зерно характерне підвищення ії урожайності, починаючи від площі посіву від 1000 га, що характерне для інтенсивного способу ведення господарства (табл. 6).

В той же час вся північна частина України (зона Полісся та передгірні і гірські райони) $€$ зонами 3 порівняно невисокою родючістю ґрунтів, вони не придатні для вирощування таких поширених в Україні культур, як зернові та зернобобові. Відомо, що в зоні достатнього зволоження (північ та захід України) при плановій економіці найбільш прибутковими культурами були хміль, льон, картопля, які на даний час $є$ збитковими. Єдиним ефективним джерелом надходження коштів у даному регіоні для абсолютної більшості сільськогосподарських виробників залишається продукція озимих зернових [7, с. 311]. Тому відбувається нарощування виробництва зерна в усіх регіонах країни, не залежно від природно-кліматичних умов та якості ґрунтів.

За досліджуваний період виробництво зернових та зернобобових культур на одну особу зросло найбільше у Чернігівській (4,44 рази), Сумській (3,44 рази), Житомирській (2,37 рази),
Хмельницькій (2,35 рази) областях. Скорочення виробництва зернових та зернобобових культур на одну особу відбулося у Одеській області - на 18,7 \% та Луганській області - на 1,2\%. 3 однієї сторони позитивною тенденцією $\epsilon$ нарощування обсягів виробництва зернових та зернобобових культур на регіональному рівні, а негативною тенденцією $€$ поступове скорочення чисельності населення, яке приймалося до розрахунку. Аналіз даних показує, що у 2000 р. у порівняні 3 началом періоду дослідження 1990 р. відбувається спад виробництва у всіх регіонах держави, а починаючи з 2010 р. і до нині відбувається нарощування зерновиробництва у регіонах. Найвищі показники обсягів зерновиробництва на одну особу в розрізі областей України були досягнуті у 2018-2019 рр. (табл. 7).

Одним із важливих чинників конкурентоспроможності продукції зернової галузі $\epsilon$ собівартість ії виробництва. За цим показником вітчизняний агробізнес ще спроможний конкурувати 3 виробниками інших країн світу. Однак за останні 5 років спостерігається тенденція суттєвого зростання рівня витрат [9]. Найбільшу частку в структурі витрат зернових та зернобобових культур займають прямі матеріальні витрати 54,2 \%, на другому місці знаходяться інші прямі витрати та загальновиробничі витрати у розмірі 40,4 \%, і найменшу частку в структурі витрат займають прямі витрати на оплату праці - 5,4 \% (табл. 8).

Найбільшу частку в структурі прямих матеріальних витрат виробництва зернових та зернобобових культур 54,2 \% займають витрати на мінеральні добрива 20,7\%, витрати на насіння та посадковий матеріал 10,9\%, пальне і паливно-мастильні матеріали $-9,8 \%$, а решта матеріальних витрат складає 12,8 (рис. 1).

Групування сільськогосподарських підприємств України

Таблиця 6 за розмірами зібраної площі кукурудзи на зерно у 2020 р.

\begin{tabular}{|l|c|c|c|c|c|}
\hline \multirow{2}{*}{ Площа, га } & \multicolumn{2}{|c|}{ Кількість підприємств } & \multicolumn{2}{|c|}{ Обсяг виробництва } & Урожайність, \\
\cline { 2 - 5 } & од. & \% & тис. т & \% & гга \\
\hline до 100,00 & 8988 & 59,4 & 1324,7 & 5,0 & 41,6 \\
\hline $100,01-200,00$ & 2049 & 13,6 & 1467,8 & 5,6 & 48,9 \\
\hline $200,01-500,00$ & 2155 & 14,3 & 3805,4 & 14,5 & 55,4 \\
\hline $500,01-1000,00$ & 984 & 6,5 & 4083,1 & 15,5 & 58,9 \\
\hline $1000,01-2000,00$ & 554 & 3,7 & 4652,6 & 17,7 & 62,9 \\
\hline $2000,01-3000,00$ & 168 & 1,1 & 2788,8 & 10,6 & 67,1 \\
\hline більше 3000,00 & 217 & 1,4 & 8157,8 & 31,1 & 68,9 \\
\hline Всього по підприємствам & 15115 & 100,0 & 26280,2 & 100,0 & 60,9 \\
\hline
\end{tabular}


Таблиця 7

Виробництво зернових і зернобобових культур на одну особу

\begin{tabular}{|l|c|c|c|c|c|c|c|c|}
\hline \multirow{2}{*}{ область } & \multicolumn{7}{|c|}{ Роки } & 2020 p. до \\
\cline { 2 - 9 } & $\mathbf{1 9 9 0}$ & $\mathbf{2 0 0 0}$ & $\mathbf{2 0 1 0}$ & $\mathbf{2 0 1 5}$ & $\mathbf{2 0 1 8}$ & $\mathbf{2 0 1 9}$ & $\mathbf{2 0 2 0}$ & $\mathbf{1 9 9 0}$ р., \% \\
\hline Вінницька & 1601 & 969 & 1890 & 2346 & 3770 & 3823 & 2612 & 163,1 \\
\hline Волинська & 865 & 472 & 559 & 1019 & 1193 & 1251 & 1361 & 157,3 \\
\hline Дніпропетровська & 910 & 432 & 810 & 1184 & 1084 & 1343 & 1120 & 123,1 \\
\hline Донецька & 478 & 205 & 404 & 359 & 321 & 475 & 483 & 101,0 \\
\hline Житомирська & 887 & 510 & 848 & 1166 & 1978 & 2255 & 2102 & 237,0 \\
\hline Закарпатська & 242 & 132 & 205 & 264 & 299 & 312 & 261 & 107,9 \\
\hline Запорізька & 1476 & 587 & 1055 & 1550 & 1303 & 1968 & 1768 & 119,8 \\
\hline Івано-Франківська & 350 & 178 & 251 & 498 & 585 & 543 & 606 & 173,1 \\
\hline Київська & 461 & 320 & 444 & 609 & 868 & 891 & 629 & 136,4 \\
\hline Кіровоградська & 2583 & 1193 & 2342 & 3392 & 3958 & 4627 & 2902 & 112,3 \\
\hline Луганська & 654 & 169 & 352 & 449 & 537 & 675 & 646 & 98,8 \\
\hline Львівська & 366 & 181 & 244 & 539 & 570 & 653 & 642 & 175,4 \\
\hline Миколаївська & 2021 & 716 & 1855 & 2494 & 2353 & 2788 & 2120 & 104,9 \\
\hline Одеська & 1014 & 633 & 1225 & 1458 & 1814 & 1576 & 824 & 81,3 \\
\hline Полтавська & 1964 & 847 & 1910 & 3714 & 4507 & 4390 & 3662 & 186,5 \\
\hline Рівненська & 736 & 419 & 552 & 948 & 1087 & 1292 & 1255 & 170,5 \\
\hline Сумська & 1319 & 729 & 1135 & 3339 & 4109 & 4124 & 4543 & 344,4 \\
\hline Тернопільська & 1124 & 642 & 1161 & 2059 & 2509 & 2590 & 2742 & 244,0 \\
\hline Харківська & 941 & 430 & 459 & 1545 & 1426 & 1656 & 1834 & 194,9 \\
\hline Херсонська & 2227 & 974 & 1389 & 2462 & 2176 & 2653 & 2661 & 119,5 \\
\hline Хмельницька & 1356 & 855 & 1310 & 2152 & 3041 & 3015 & 3190 & 235,3 \\
\hline Черкаська & 1551 & 1116 & 1962 & 3003 & 3827 & 3802 & 2272 & 146,5 \\
\hline Чернівецька & 620 & 350 & 540 & 575 & 648 & 711 & 643 & 103,7 \\
\hline Чернігівська & 1233 & 655 & 1375 & 3346 & 4847 & 5017 & 5477 & 444,2 \\
\hline Україна & 983 & 497 & 856 & 1403 & 1657 & 1788 & 1555 & 158,2 \\
\hline
\end{tabular}

Джерело: розроблено автором на основі [6]

Основними показниками ефрективності виробництва зерна є: урожайність, ц/га; якісні параметри продукції; затрати праці на 1 ц, люд.год.; собівартість та ціна реалізації 1 ц, грн.; прибуток, грн. на: 1 ц і на 1 га; рівень рентабельності та рентабельність продажу, \% [2, с. 32]. Аналізуючи рентабельність виробництва зерна приходимо до висновку, що у порівнянні 3 2018 р. відбулося зниження з 24,7 \% до 11,8 \% у 2019 р. За досліджуваний період 1996-2019 рр. найвищий рівень рентабельності спостерігався у 1996 р. - 64,6 \%, 2000 р. - 64,8 \%, високий рівень рентабельності був у 2003 р. - 45,8 \%, 2001 p. - 43,3 \%, 2015 p. - 43,1 \%. Найнижчий рівень рентабельності характерний для 2013 p. - 1,5 \%, 1998 p. - 1,9 \%, 2005 p. - 3,1\%. Починаючи з 2015 р. і до 2019 р. відбувається постійне зниження рівня рентабельності виробництва зернових та зернобобових культур, при цьому темп приросту склав - 7,4 \% (табл. 9).

Важливим показником економічної ефективності виробництва зерна $€$ собівартість продукції. Вона відображає якість роботи господарств і значною мірою визначає рівень його прибутковості. Покрити зростання виробничих витрат та для забезпечення високої есрективності виробництва зерна, покликана ціна реалізації. Рівень рентабельності зерна фрормується і залежить від його собівартості та середньої ціни реалізації. Також ціна реалізації залежить від якості продукції зернової галузі. Так, щодо пшениці ціни реалізації встановлені з урахуванням вмісту білка і клейковини [2, с. 32]. За 1996-2019 рр. темпи приросту середньої ціни реалізації зернових та зернобобових культур сільськогосподарських підприємств зріс на 15,3 \%. Однак, у 2018 р. ціна реалізації була вища і становила 431,5 грн/ц, ніж у 2019 р. - 386,8 грн/ц, яка зменшилась на 44,7 грн/ц або на $10 \%$.

Напрямами підвищення ефективності виробництва зернових та зернобобових культур сільськогосподарських підприємств $€$ : 
Таблиця 8

Структура витрат на виробництво зернових та зернобобових культур сільськогосподарських підприємств у 2019 р.

\begin{tabular}{|c|c|c|c|c|}
\hline Показник & $\begin{array}{l}\text { Витрати } \\
\text { усього }\end{array}$ & $\begin{array}{c}\text { Прямі } \\
\text { матеріальні } \\
\text { витрати }\end{array}$ & $\begin{array}{c}\text { Прямі витрати } \\
\text { на оплату } \\
\text { праці }\end{array}$ & $\begin{array}{c}\text { Інші прямі } \\
\text { витрати та } \\
\text { загально- } \\
\text { виробничі } \\
\text { витрати }\end{array}$ \\
\hline \multicolumn{5}{|c|}{ Витрати на виробництво зернових та зернобобових культур, тис. грн } \\
\hline $\begin{array}{l}\text { Продукція рослинництва } \\
\text { - усього }\end{array}$ & 281445559,7 & 153116287,6 & 16113849,6 & 112215422,5 \\
\hline $\begin{array}{l}\text { Культури зернові та } \\
\text { зернобобові - усього }\end{array}$ & 158042684,6 & 85612489,9 & 8509526,5 & 63920668,2 \\
\hline \multicolumn{5}{|l|}{ у тому числі } \\
\hline пшениця & 64252352,1 & 36262301,1 & 3726989,3 & 24263061,7 \\
\hline кукурудза на зерно & 72864318,6 & 37545119,5 & 3475756,8 & 31843442,3 \\
\hline ячмінь & 14852371,3 & 8371101,5 & 910332,1 & 5570937,7 \\
\hline жито & 593471,0 & 349385,7 & 39150,6 & 204934,7 \\
\hline овес & 347200,4 & 194515,0 & 31165,3 & 121520,1 \\
\hline гречка & 188455,6 & 94659,3 & 14385,5 & 79410,8 \\
\hline просо & 525325,3 & 288394,1 & 34227,2 & 202704 \\
\hline культури зернобобові & 3195497,6 & 1759109,5 & 203774,6 & 1232613,5 \\
\hline Боби сої & 18888085,6 & 8988031,9 & 1077413,8 & 8822639,9 \\
\hline \multicolumn{5}{|c|}{ Відношення до усіх витрат, \% } \\
\hline $\begin{array}{l}\text { Продукція рослинництва } \\
\text { - усього }\end{array}$ & 100,0 & 54,4 & 5,7 & 39,9 \\
\hline $\begin{array}{l}\text { Культури зернові та } \\
\text { зернобобові - усього }\end{array}$ & 100,0 & 54,2 & 5,4 & 40,4 \\
\hline \multicolumn{5}{|l|}{ у тому числі } \\
\hline пшениця & 100,0 & 56,4 & 5,8 & 37,8 \\
\hline кукурудза на зерно & 100,0 & 51,5 & 4,8 & 43,7 \\
\hline ячмінь & 100,0 & 56,4 & 6,1 & 37,5 \\
\hline жито & 100,0 & 58,9 & 6,6 & 34,5 \\
\hline овес & 100,0 & 56,0 & 9,0 & 35,0 \\
\hline гречка & 100,0 & 50,2 & 7,7 & 42,1 \\
\hline просо & 100,0 & 54,9 & 6,5 & 38,6 \\
\hline культури зернобобові & 100,0 & 55,0 & 6,4 & 38,6 \\
\hline Боби сої & 100,0 & 47,6 & 5,7 & 46,7 \\
\hline
\end{tabular}

Джерело: розроблено автором на основі [8]

1. Додержання оптимальної структури посівних площ, яка покращить ґрунтовий покрив та підвищить родючість ґрунтів, збільшить вміст гумусу та поживних речовин. Занепад галузі тваринництва та орієнтація на експорт призвела до збільшення посівних площ зернових та зернобобових культур і зменшення посівів кормових культур. Відповідно до Постанова Кабінету Міністрів України від 11.02.2010 р. № 164 «Про затвердження нормативів оптимального співвідношення культур у сівозмінах в різних природно-сільськогосподарських регіонах» у структурі посівних площ зернові та зернобобові культури мають займати у Поліссі - 35-80 \%, Лісостепу 25-95 \%, Степу 45-82 \% [11].

2. Посилення фрінансово-економічного стану сільськогосподарських підприємств шляхом державної підтримки, надання пільг та сприятливих кредитних умов дозволить спрямувати додаткові кошти на розширене відтворення матеріально-технічних ресурсів, впроваджувати інноваційні методи виробництва, новітні технології вирощування зернових культур, придбання високоврожайних сортів.

3. Хоча у структурі витрат найбільший відсоток займають витрати на мінеральні добрива, але це призводить до десріциту 
25

20,7

20

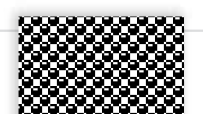

15

10,9
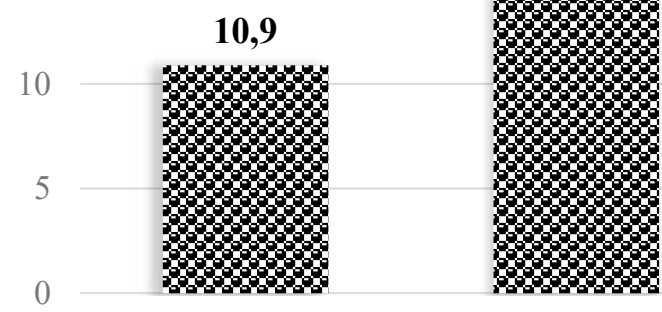

12,8

насіння та посадковий мінеральні добрива матеріал

9,8

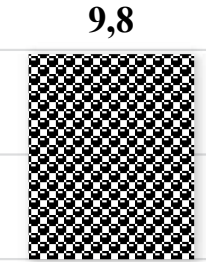

пальне і мастильні матеріали

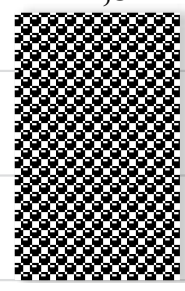

решта матеріальних витрат

Рис. 1. Структура прямих матеріальних витрат на виробництво зернових та зернобобових культур у 2019 р. по Україні, \%

Джерело: розроблено автором на основі [8]

Таблиця 9

Темпи приросту цін та рентабельності виробництва зернових та зернобобових культур сільськогосподарських підприємств

\begin{tabular}{|c|c|c|c|c|}
\hline Рік & Середні ціни & Індекс & $\begin{array}{c}\text { Рівень } \\
\text { рентабельності }\end{array}$ & Індекс \\
\hline 1996 & 16,8 & & 64,6 & \\
\hline 1997 & 17,6 & 1,0476 & 37,5 & 0,5805 \\
\hline 1998 & 15,4 & 0,8750 & 1,9 & 0,0507 \\
\hline 1999 & 20,0 & 1,2987 & 12,0 & 6,3158 \\
\hline 2000 & 44,4 & 2,2200 & 64,8 & 5,4000 \\
\hline 2001 & 38,1 & 0,8581 & 43,3 & 0,6682 \\
\hline 2002 & 31,3 & 0,8215 & 19,3 & 0,4457 \\
\hline 2003 & 53,5 & 1,7093 & 45,8 & 2,3731 \\
\hline 2004 & 45,3 & 0,8467 & 20,1 & 0,4389 \\
\hline 2005 & 41,8 & 0,9227 & 3,1 & 0,1542 \\
\hline 2006 & 51,5 & 1,2321 & 7,4 & 2,3871 \\
\hline 2007 & 83,4 & 1,6194 & 28,7 & 3,8784 \\
\hline 2008 & 77,9 & 0,9341 & 16,4 & 0,5714 \\
\hline 2009 & 79,9 & 1,0257 & 7,3 & 0,4451 \\
\hline 2010 & 112,1 & 1,4030 & 13,9 & 1,9041 \\
\hline 2011 & 137,4 & 1,2257 & 26,1 & 1,8777 \\
\hline 2012 & 154,7 & 1,1259 & 15,2 & 0,5824 \\
\hline 2013 & 130,0 & 0,8403 & 1,5 & 0,0987 \\
\hline 2014 & 180,1 & 1,3854 & 25,8 & 17,2000 \\
\hline 2015 & 291,2 & 1,6169 & 43,1 & 1,6705 \\
\hline 2016 & 341,4 & 1,1724 & 37,8 & 0,8770 \\
\hline 2017 & 377,2 & 1,1049 & 25,0 & 0,6614 \\
\hline 2018 & 431,5 & 1,1440 & 24,7 & 0,9880 \\
\hline 2019 & 386,8 & 0,8964 & 11,8 & 0,4777 \\
\hline Темп росту & & 115,3 & & 92,6 \\
\hline Темп приросту, \% & & 15,3 & & $-7,4$ \\
\hline & & & & \\
\hline
\end{tabular}


поживних речовин у ґрунті, бо мала кількість тваринницьких фрерм не може задовільними попит на органіку, що призводить до обмеженості внесення органічних добрив та порушення балансу поживних речовин у ґрунті. Так, за даними національного інституту стратегічних досліджень для уникнення десріциту гумусу на 1 га ріллі необхідно додати органіки у Поліссі - 13-14 т, у Лісостепу - 11-12 т, Степу - 8-9 т [12].

4. Ключовим фрактором успішної фрінансово-економічної діяльності сільськогосподарських товаровиробників $€$ налагоджена робота маркетингової системи зернової продукції, яка дозволить уникнути посередників на шляху зберігання та збуту. Особливо це важливо для дрібних фермерських господарств, у яких відсутні власні сушарки та зерносховища. Для продажу трейдери створюють товарну партію зерна за об'ємом, стандартами, одноманітністю та доступністю для продажу за наявності сертифрікатів якості, карантину, мита тощо. Тому дрібні товаровиробники мають розвивати кооперативи, консолідації, асоціації.

Висновки. Збільшення обсягів виробництва зернових та зернобобових культур позитивно вплине на створення нових робочих місць, зростання заробітної плати працівникам, підвищить вимоги до рівня їх кваліфрі- кації на основі конкурентоспроможності та експортної орієнтованості на зовнішні ринки аграрної продукції завдяки вирощуванню якісної продукції, яка відповідає світовим стандартам. На теперішній час зерновиробництво $€$ найприбутковішою галуззю, особливо вирощування кукурудзи на зерно та пшениці. Тому спостерігається зростання посівних площ цих сільськогосподарських культур незалежно від природно-кліматичної зони та рекомендацій районування культур, підвищення їх урожайності і продуктивності праці, зростання виробництва зерна на одну особу в регіонах, і відбувається концентрація зернового виробництва. Як показало дослідження, чим більша площа посівів зернових та зернобобових культур, тим більша врожайність і валовий збір вирощеної продукції, бо ширші можливості для впровадження новітніх технологій вирощування, внесення мінеральних та органічних добрив, застосування високоврожайного посівного матеріалу, вирощування якісної продукції, і більша можливість збутової діяльності, ніж у дрібних товаровиробників. Тому подальшого дослідження заслуговують питання підвищення урожайності у дрібних фрермерських господарствах 3 низькою врожайністю, обмеженнями на ринку збуту продукції, можливостями підвищення ціни реалізації та якості вирощуваної продукції.

\section{СПИСОК ВИКОРИСТАНИХ ДЖЕРЕЛ:}

1. Заїка С.О., Романова Р.Р., Курган В.О. Підвищення економічної ефективності зерновиробництва в Україні. Причорноморські економічні студіï. 2018. Вип. 25. С. 39-42. URL: http://nbuv.gov.ua/UJRN/bses_2018_25_10

2. Гуторова О.О., Стасенко О.М. Господарський механізм ефективного виробництва зерна в сільськогосподарських підприємствах: теорія та практика : монографрія. Харк. нац. аграр. ун-т ім. В.В. Докучаєва. Харків : ХНАУ, Федорко, 2014. 242 с.

3. Сосновська О.О., Білун С.О., Бурлака О.П. Економічна ефективність виробництва зерна та шляхи ії підвищення в сільськогосподарських підприємствах Полтавської області. Вісник Полтавської державної аграрної академії. Полтава : ПДАА, 2011. С. 284-290. URL: https://www.pdaa.edu.ua/sites/default/files/ nppdaa/2011/01/284.pdf

4. Христенко Г.М. Розвиток та напрями підвищення ефективності зернової галузі. Вісник Національного технічного університету «ХПІ». Серія : Актуальні проблеми управління та фрінансово-господарської діяльності підприємства. 2013. № 53. C. 182-188. URL: http://nbuv.gov.ua/UJRN/vcpiay_2013_53_37

5. Забуранна Л.В. Економічна ефрективність виробництва зерна та шляхи їі підвищення в сільськогосподарських підприємствах. Економіка АПК. 2014. № 3. C. 55-61. URL: http://nbuv.gov.ua/UJRN/E_apk_2014_3_10

6. Прокопенко О., Вишневська О. Рослинництво України 2020 р.: стат. збірник. Державна служба статистики України. Київ : ДССУ, 2021. 183 c. URL: http://www.ukrstat.gov.ua/

7. Новікова М.Ф. Економічний аналіз виробництва зерна на Житомирщині. Вісник ДАУ. 2003. № 1. C. 306-313. URL: http://ir.znau.edu.ua/handle/123456789/6720

8. Прокопенко О., Вишневська О. Витрати підприємств на виробництво продукції сільського господарства у 2019 р. : стат. збірник. Державна служба статистики України. Київ : ДССУ, 2020. 18 с. URL: http://www.ukrstat.gov.ua/

9. Кернасюк Ю.В. Зернова галузь: розвиток, тренди і прогнози в умовах зміни клімату. Агробізнес сьогодні. 2020. URL: http://agro-business.com.ua/agro/ekonomichnyi-hektar/item/18345 
10. Прокопенко О., Вишневська О. Середні ціни продукції сільського господарства, реалізованої підприємствами (1996-2020рр.) : стат. інформація. Державна служба статистики України. Київ : ДССУ, 2020.1 с. URL: http://www.ukrstat.gov.ua/

11.Про затвердження нормативів оптимального співвідношення культур у сівозмінах в різних природно-сільськогосподарських регіонах : Постанова Кабінету Міністрів України від 11.02.2010 р. № 164 . URL: https://www.kmu.gov.ua/npas/243288952

12. Щодо шляхів підвищення ефективності використання земель сільськогосподарського призначення в Україні : аналіт. записка. Національний інститут стратегічних досліджень. URL: https://niss.gov.ua/doslidzhennya/ ekonomika/schodo-shlyakhiv-pidvischennya-efektivnosti-vikoristannya-zemel\#_ftn11

\section{REFERENCES:}

1. Zayika S.O., Romanova R.R., Kurhan V.O. (2018) Pidvyshchennya ekonomichnoyi efektyvnosti zernovyrobnytstva v Ukrayini [Improving the economic efficiency of grain production in Ukraine]. Prychornomors'ki ekonomichni studiyi, no. 25, pp. 39-42. (in Ukrainian)

2. Hutorova O.O., Stasenko O.M. (2014) Hospodars'kyy mekhanizm efektyvnoho vyrobnytstva zerna v sil's'kohospodars'kykh pidpryyemstvakh: teoriya ta praktyka [Economic mechanism of efficient grain production in agricultural enterprises: theory and practice]: monohrafiya [a monograph]. Kharkiv: KHNAU, Fedorko, 242 p. (in Ukrainian)

3. Sosnovs'ka O.O., Bilun S.O., Burlaka O.P. (2011) Ekonomichna efektyvnist' vyrobnytstva zerna ta shlyakhy yiyi pidvyshchennya $v$ sil's'kohospodars'kykh pidpryyemstvakh Poltavs'koyi oblasti [Economic efficiency of grain production and ways to increase it in agricultural enterprises of Poltava region]. Visnyk Poltavs'koyi derzhavnoyi ahrarnoyi akademiyi. Poltava: PDAA, pp. 284-290. (in Ukrainian)

4. Khrystenko H.M. (2013) Rozvytok ta napryamy pidvyshchennya efektyvnosti zernovoyi haluzi [Development and increasing directions of grain industry efficiency]. Visnyk Natsional'noho tekhnichnoho universytetu, no. 53, pp. 182-188. (in Ukrainian)

5. Zaburanna L.V. (2014) Ekonomichna efektyvnist' vyrobnytstva zerna ta shlyakhy yiyi pidvyshchennya v sil's'kohospodars'kykh pidpryyemstvakh [Economic efficiency of grain production and ways to increase it in agricultural enterprises]. Ekonomika APK, no. 3, pp. 55-61. (in Ukrainian)

6. Prokopenko O., Vyshnevs'ka O. (2021) Roslynnytstvo Ukrayiny 2020 r. [Crop production of Ukraine 2020]. Derzhavna sluzhba statystyky Ukrayiny. Kyiv: DSSU, 183 p. (in Ukrainian)

7. Novikova M.F. (2003) Ekonomichnyy analiz vyrobnytstva zerna na Zhytomyrshchyni [Economic analysis of grain production in Zhytomyr region]. Visnyk DAU, vol. 1, pp. 306-313. (in Ukrainian)

8. Prokopenko O., Vyshnevs'ka O. (2020) Vytraty pidpryyemstv na vyrobnytstvo produktsiyi sil's'koho hospodarstva u 2019 r. [Expenditures of enterprises for the production of agricultural products in 2019]. Derzhavna sluzhba statystyky Ukrayiny. Kyiv: DSSU, 18 p. (in Ukrainian)

9. Kernasyuk Yu.V. (2020) Zernova haluz': rozvytok, trendy i prohnozy $v$ umovakh zminy klimatu [Grain industry: development, trends and forecasts in the context of climate change]. Ahrobiznes s'ohodni. Available at: http://agro-business.com.ua/agro/ekonomichnyi-hektar/item/18345

10. Prokopenko O., Vyshnevs'ka O. (2020) Seredni tsiny produktsiyi sil's'koho hospodarstva, realizovanoyi pidpryyemstvamy (1996-2020 rr.) [Average prices of agricultural products sold by enterprises (1996-2020)]. Derzhavna sluzhba statystyky Ukrayiny. Kyiv: DSSU. (in Ukrainian)

11.Pro zatverdzhennya normatyviv optymal'noho spivvidnoshennya kul'tur u sivozminakh $v$ riznykh pryrodnosil's'kohospodars'kykh rehionakh [On approval of standards for the optimal ratio of crops in crop rotations in different natural and agricultural regions]. Postanova Kabinetu Ministriv Ukrayiny vid 11.02.2010 r. № 164. Available at: https://www.kmu.gov.ua/npas/243288952

12. Shchodo shlyakhiv pidvyshchennya efektyvnosti vykorystannya zemel' sil's'kohospodars'koho pryznachennya $v$ Ukrayini [On ways to increase the efficiency of agricultural land use purpose in Ukraine]. Natsional'nyy instytut stratehichnykh doslidzhen'. Available at: https://niss.gov.ua/doslidzhennya/ekonomika/schodo-shlyakhiv-pidvischennya-efektivnosti-vikoristannya-zemel\#_ftn11 